\title{
Research progress of novel adsorption processes in water purification: A review
}

\author{
QU Jiuhui*
}

State Key Laboratory of Environmental Aquatic Chemistry, Research Center for Eco-Environmental Sciences,

Chinese Academy of Sciences, Beijing 100085, China. E-mail: jhqu@rcees.ac.cn

\begin{abstract}
As an effective, efficient, and economic approach for water purification, adsorbents and adsorption processes have been widely studied and applied in different aspects for a long time. In the recent years, a lot of novel adsorption processes have been developed for enhancing the efficiency of removing the organic and inorganic contaminants from water. This article reviews some new adsorbents and advanced adsorption methods that specialize in their compositions, structures, functions, and characteristics used in water treatment. The review emphasizes adsorption/catalytic oxidation process, adsorption/catalytic reduction process, adsorption coupled with redox process, biomimetic sorbent and its sorption behaviors of POPs, and modified adsorbents and their water purification efficiency.
\end{abstract}

Key words: adsorbents; adsorption; pollutants; water purification

\section{Introduction}

Various treatment techniques and processes have been used to remove the pollutants from contaminated water. Among all the approaches proposed, adsorption is one of the most popular methods and is currently considered as an effective, efficient, and economic method for water purification. The adsorbents used include activated carbon (Nouri et al., 2002; Pereira et al., 2003), clay minerals (Celis et al., 2000; Abollino et al., 2003), zeolites (Oliveira et al., 2004), metal oxides (Wu et al., 2004, 2005; Zhang et al., 2007a), agricultural wastes (Robinson et al., 2002), biomass (Loukidou et al., 2003) and polymeric materials (Atia et al.,2003).

Due to its high surface area, porous structure, and special surface reactivity, activated carbon has been the most popular and widely used adsorbent in water purification all over the world (Babel and Kurniawan, 2003). This adsorbent is highly inert and thermally stable, and it can be used over a broad $\mathrm{pH}$ range. Although it has great capacity of adsorbing various organic compounds and can be easily modified by chemical treatment to increase its adsorption capacity, activated carbon has several disadvantages. It is expensive and the powdered one is difficult to be separated from aquatic system when it becomes exhausted or the effluent reaches the maximum allowable discharge level. Furthermore, adsorption process just transfers pollutants from one phase to another rather than eliminating them from the environment. The regeneration of exhausted activated carbon by chemical and thermal procedure is also expensive and results in loss of the sorbent. Recently,

\footnotetext{
*Corresponding author. E-mail: jhqu@ rcees.ac.cn
}

numerous approaches have been investigated for the development of cheaper and more effective novel composite adsorbents (Oliveira et al., 2004; Gu et al., 2005; Machado et al., 2006; Zhang et al., 2007b). These composite materials deserve particular attention because they combine the properties and advantages of each of their components. They represent an interesting and attractive alternative as adsorbents and/or catalysts due to their high reactivity and excellent selectivity towards specific pollutant compounds. This article describes the latest development in the above aspects.

\section{Adsorption/catalytic oxidation process}

Adsorption/catalytic oxidation process can be divided into two categories: in situ and out situ adsorption with catalytic oxidation, according to whether adsorption process and oxidation process occur in the same reactor. Evidently, the photocatalytic degradation of organic pollutants by $\mathrm{TiO}_{2}$ supported on adsorbents belongs to the former. The adsorption and catalytic oxidation of dyes by magnetic metal oxide composite (Wu et al., 2004) can be identified under the latter described.

\subsection{Photocatalytic degradation by $\mathrm{TiO}_{2}$ supported on adsorbents}

Titanium dioxide has been widely used as photocatalytic material for removing toxic chemicals from waters. However, certain limitations exist in using bare $\mathrm{TiO}_{2}$ in photocatalytic reactors. For example, due to small size (about $4-30 \mathrm{~nm}$ ) $\mathrm{TiO}_{2}$ aggregates rapidly in a suspension loosing its effective surface area as well as the catalytic 
efficiency (Bhattacharyya et al., 2004). It also shows low adsorption ability for the pollutants due to its nonporous property (Torimoto et al., 1997), especially for the non-polar organic compounds due to its polar surface (Lepore et al., 1996). Thus, in recent years, attempts have been made to immobilize fine $\mathrm{TiO}_{2}$ on porous adsorbent materials like silica (Lepore et al., 1996; Xu et al., 1999), activated carbon (Torimoto et al., 1997; Yoneyama and Torimoto, 2000), alumina (Anderson and Bard, 1997), clay and zeolites (Sampath et al., 1994; Xu et al., 1997; Bhattacharyya et al., 2004) to produce composite adsorbent/catalyst. The sol-gel route is well established as an excellent method to prepare the $\mathrm{TiO}_{2}$-based materials.

$\mathrm{TiO}_{2}$ supported on adsorbent provides higher specific surface area and facilitates more effective adsorption sites than bare $\mathrm{TiO}_{2}$ (Anderson and Bard, 1995; Takeda et al., 1997). And the degradation rates of organic pollutants are usually better than that of bare $\mathrm{TiO}_{2}$. For example, Bhattacharyya et al. (2004) loaded $\mathrm{TiO}_{2}$ on three different kinds of porous adsorbents, mesoporous (MCM-41), microporous ( $\beta$-zeolite), and pillared structure (montmorillonite) using sol-gel method, and the photocatalytic efficiency of the supported catalysts was evaluated using an azo-dye, namely, Orange II as model compound in water under different operating conditions. Their results revealed that these three supported composite catalysts were more effective than bare $\mathrm{TiO}_{2}$ in photodegradation of Orange II. A similar result was obtained by Machado et al. (2006b) who dispersed $\mathrm{TiO}_{2}$ on the surface of high surface area vermiculite to prepare composite adsorbent/catalyst for the decomposition of reactive textile dye, namely, Drimaren Red. Noticeably, the composite with a high specific area can be floating on the water surface. In their opinions, the enhanced decomposition rates are attributed to the increased condensation of organic substrates on the supported catalyst by adsorption and the reduced electronhole recombination process on the surface.

\subsection{Adsorption and catalytic oxidation by magnetic metal oxide composite}

Another kind of composite adsorbent/catalyst, which processes high adsorption capacity and catalytic activi- ty towards organic compounds, is magnetic metal oxide composite and magnetic metal oxide supported adsorbents. Wu and co-workers (Wu et al., 2004, 2005) firstly prepared magnetic metal oxide composite adsorbents (powder $\mathrm{CuFe}_{2} \mathrm{O}_{4}$ and $\mathrm{MnO}-\mathrm{Fe}_{2} \mathrm{O}_{3}$ ) by a simple co-precipitation method from environmental friendly and low cost materials. These adsorbents have a relatively high surface area, a smaller particle size, and porous structure. In particular, the excellent magnetic property of the powders makes them to be easily recovered by magnetic separation technology after adsorption or regeneration, which overcomes the disadvantage of separation difficulty of common powdered adsorbents.

The adsorption performance of the magnetic composites was studied using azo dye, namely, Acid Red B (ARB) as a model compound. The results demonstrated that both the $\mathrm{CuFe}_{2} \mathrm{O}_{4}$ and $\mathrm{MnO}-\mathrm{Fe}_{2} \mathrm{O}_{3}$ adsorbents had high adsorption rate and the maximal adsorption capacities for ARB are 86.8 and $105.3 \mathrm{mg} / \mathrm{g}$, respectively. Through systematic thermal degradation experiments and in situ Fourier transform infrared (FTIR), along with by-product analysis by GC-MS, the catalytic combustion process of $\mathrm{ARB}$ on $\mathrm{CuFe}_{2} \mathrm{O}_{4}$ was thoroughly investigated. It was found that the $\mathrm{CuFe}_{2} \mathrm{O}_{4}$ had high catalytic activity, and it greatly lowered the degradation temperature of ARB. This can be easily seen from Fig.1 (Wu et al., 2004). Similarly, $\mathrm{MnO}-\mathrm{Fe}_{2} \mathrm{O}_{3}$ also had high catalytic activity, despite being not higher than that of $\mathrm{CuFe}_{2} \mathrm{O}_{4}$. The regeneration experimental results suggested that these adsorbents could be used repeatedly over many cycles.

On the other hand, Peng et al. (2006) prepared a montmorillonite- $\mathrm{Cu}(\mathrm{II}) / \mathrm{Fe}(\mathrm{III})$ oxides magnetic composite adsorbent using the same method of co-precipitation. In comparison with that of montmorillonite, the specific surface area of the composite increased remarkably. The composite was used to remove humic acid from water and exhibited favorable adsorption capacity. The exhausted montmorillonite- $\mathrm{Cu}(\mathrm{II}) / \mathrm{Fe}(\mathrm{III})$ oxides were regenerated under $300^{\circ} \mathrm{C}$ and the result confirmed the high catalytic activity of copper ferrite once again.

The magnetic composite adsorbents are good for adsorption of pollutants and their separation from water. But they
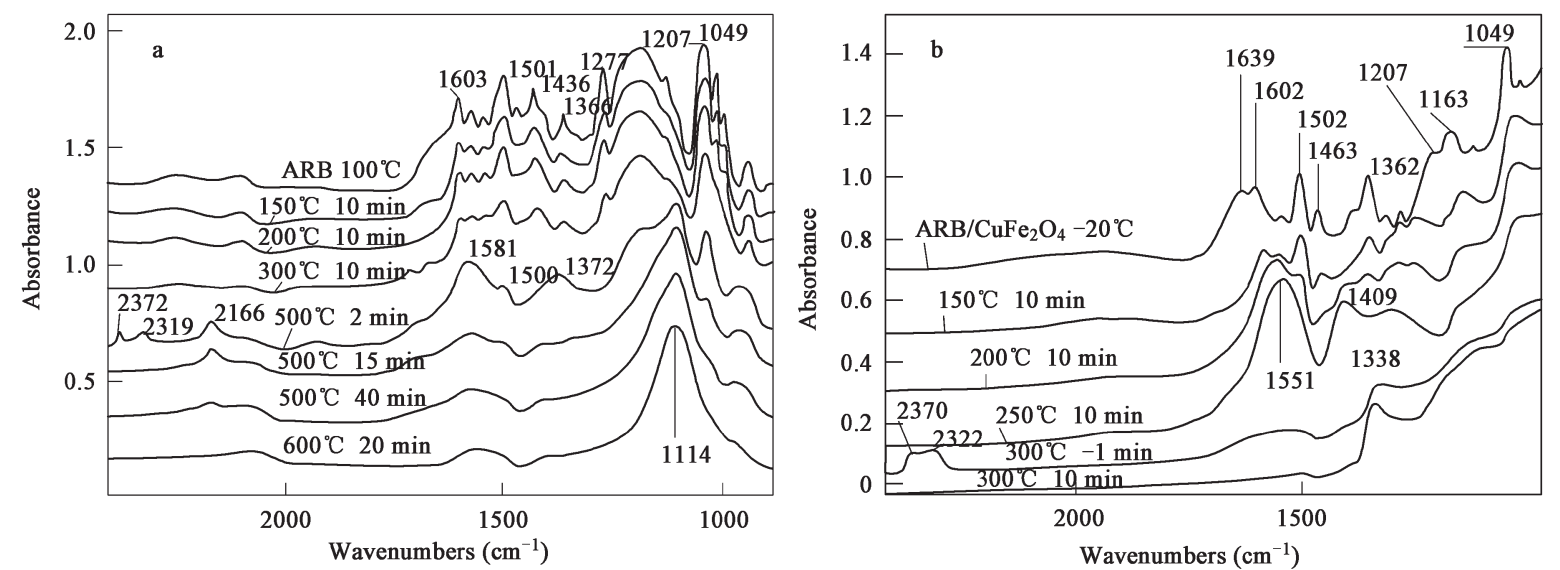

Fig. 1 FTIR spectra of Acid Red B (ARB) combustion in the absence of $\mathrm{CuFe}_{2} \mathrm{O}_{4}$ (a) and $\mathrm{ARB} / \mathrm{CuFe}_{2} \mathrm{O}_{4}$ combustion (b) at different temperatures (Wu et al., 2004). 
also have some shortcomings. For example, only certain kind of pollutants can be adsorbed by them.

Up to now, numerous new composite adsorbents have been developed for water purification by adsorption/catalytic oxidation process. Every one has its own advantage and disadvantage. It seems that these magnetic composite adsorbents that own high catalytic activity and are easily separated from aquatic system are more promising in practical application.

\section{Adsorption/catalytic reduction process}

Adsorption/catalytic reduction process has been found to be efficiently used in water purification. In the recent years, many kinds of adsorbents with the catalytic reduction function were developed and used in removing nitrate, heavy metals, and organic pollutants from water. Here, we take the modified hydrotalcite-type (HT) adsorbent as an example.

\subsection{Hydrotalcite-type (HT) adsorbent and its modifica- tion}

HT compounds, a class of layered double hydroxides, consist of positively charged metal hydroxide layers separated from each other by anions and water molecules (Cavani et al., 1991). It was found that many kinds of cations, whose ionic radius are not too different from that of $\mathrm{Mg}^{2+}$, may be introduced inside the brucite-like sheet, and thus, HT with various compositions and structure were obtained. This feature resulted in the occurrence of more synthetic HT compounds, which consequently exploited their further application in various scopes. Wherein, the use of HT as a kind of adsorbent in the water treatment was focused by many researchers. As reported, many kinds of ions, such as inorganic anions (Kuzawa et al., 2006; Yoshioka et al., 2007), organic acids (Silverio et al., 2007), and colored organics (Orthman et al., 2007; Bouraada et al., 2007), may enter the interlayer space of HT and consequently be adsorbed. Especially, after calcinations, the reconstruction of the original hydrotalcite with the positive charge layers was obtained. Researches (Sasaki et al., 2006) indicated that Zn-Al hydrotalcite, with the intercalation of water-soluble $p$-sulfonated calix arene (CS4) in the interlayer, showed effective adsorption capacity for benzyl alcohol and $p$-nitrophenol and would be new organic-inorganic hybrid adsorbents for many organic molecules. Additionally, another important application of HT compounds was as a catalyst or catalyst support (Chang et al., 2007; Parida et al., 2007). Because of the electrostatic repulsive force between $\mathrm{M}^{\mathrm{II}}$ and $\mathrm{M}^{\mathrm{III}}$ cations on the brucite-like sheet, higher dispersion of cations may be obtained. This result facilitated the formation of the homogeneous mixtures of oxides with small crystal size after calcinations, which was usually beneficial for catalytic reaction.

\subsection{Hydrotalcite-supported Pd-Cu adsorbent for nitrite removal}

In recent years, nitrate contamination of water in many parts of the world has become a serious problem. Accordingly, the current technologies used for nitrate removal from water receive an increasing attention. Based on the property of HT, a novel hydrotalcite-supported Pd-Cu material, combining the high adsorption capacity of HT and the reduction property of active metals $(\mathrm{Pd}-\mathrm{Cu})$ for nitrate, were developed (Wang Y, 2006; Wang et al., 2007a). In this case, HT was used not only as an adsorbent but also as a catalyst support. The performance of adsorption and chemical catalytic reduction of nitrate may be promoted by each other. In these processes, nitrate ions in water may be adsorbed by HT, which would enhance the concentration of nitrate ions around active sites $(\mathrm{Pd}-\mathrm{Cu})$ on $\mathrm{HT}$, and thus, increase the catalytic reduction efficiency of nitrate. Inversely, catalytic reduction of nitrate may refresh the surface of HT, and then promote the continuous adsorption of nitrate on HT.

Table 1 shows the main characteristics of a series of powder-calcined hydrotalcite-supported $\mathrm{Pd}-\mathrm{Cu}$ materials with the same $\mathrm{Pd}-\mathrm{Cu}$ loading (about $1 \mathrm{wt} . \% \mathrm{Pd}$ and 0.25 wt.\% $\mathrm{Cu}$ ) for nitrate adsorption and catalytic reduction from water (Wang et al., 2007b). The results indicated that these materials exhibited high surface area of 183.9-236.6 $\mathrm{m}^{2} / \mathrm{g}$ and mesopore structure. The highest was obtained on the material prepared by co-precipitation method, which exhibited more homogeneous dispersion of active metal clusters by the analysis of SEM and TEM (Wang et al., 2006). Active metals of $\mathrm{Pd}$ and $\mathrm{Cu}$ on the surface of the catalyst presented both oxide and metallic state, in which metallic state was dominant. These characteristics were considered to be beneficial for the catalytic reduction reaction, and thus further evaluation on adsorption and catalytic reduction of nitrate using hydrogen as reducer were conducted.

According to the experimental results, hydrotalcitesupported $\mathrm{Pd}-\mathrm{Cu}$ materials showed effective adsorption capacity for nitrate removal from water, which followed the order: HT3 $(\mathrm{Pd}-\mathrm{Cu})>\mathrm{Pd}-\mathrm{Cu} / \mathrm{HT} 5>\mathrm{Pd}-\mathrm{Cu} / \mathrm{HT} 3$ $>\mathrm{Pd}-\mathrm{Cu} / \mathrm{HT} 2>\mathrm{Pd}-\mathrm{Cu} / \mathrm{HT} 4$. The material obtained by co-precipitation exhibited a higher adsorption capacity for nitrate than that prepared by the co-impregnation

Table 1 Chemical composition and characteristics of different hydrotalcite supported Pd-Cu materials (Wang et al., 2007b)

\begin{tabular}{|c|c|c|c|c|c|}
\hline Sample & $\begin{array}{l}\text { Atomic ratio } \\
\text { of } \mathrm{Mg} / \mathrm{Al}\end{array}$ & $\begin{array}{l}\text { Preparation } \\
\text { method }\end{array}$ & $\begin{array}{l}\text { BET } \\
\left(\mathrm{m}^{2} / \mathrm{g}\right)\end{array}$ & $\begin{array}{l}\text { Volume of } \\
\text { pores }(\mathrm{ml} / \mathrm{g})\end{array}$ & $\begin{array}{l}\text { Average diameter } \\
\text { of pores }\left(\times 10^{-10} \mathrm{~m}\right)\end{array}$ \\
\hline $\mathrm{Pd}-\mathrm{Cu} / \mathrm{HT} 2$ & 2 & impregnation & 184.7 & 0.250 & 52.17 \\
\hline $\mathrm{Pd}-\mathrm{Cu} / \mathrm{HT} 3$ & 3 & impregnation & 185.3 & 0.243 & 52.20 \\
\hline $\mathrm{Pd}-\mathrm{Cu} / \mathrm{HT} 4$ & 4 & impregnation & 183.9 & 0.241 & 54.23 \\
\hline $\mathrm{Pd}-\mathrm{Cu} / \mathrm{HT} 5$ & 5 & impregnation & 195.0 & 0.228 & 46.68 \\
\hline HT3 (Pd-Cu) & 3 & coprecipitation & 236.6 & 0.849 & 143.60 \\
\hline
\end{tabular}


method. Theoretically, the maximum adsorption amount $\left(q_{\mathrm{m}}\right)$ reached $9.44 \mathrm{mg}-\mathrm{NO}_{3}{ }^{-}-\mathrm{N} / \mathrm{g}$ for $\mathrm{HT} 3(\mathrm{Pd}-\mathrm{Cu})$ (Wang et al., 2007b).

As reported in literature (Maia et al., 2007; Laurin et al., 2006), catalytic reduction of nitrate ions obeys a consecutive reaction scheme, in which nitrite appears as an intermediate, whereas nitrogen and ammonia are the final products. Wang et al. (2007b) compared the catalytic reduction capacity of hydrotalcite-supported Pd$\mathrm{Cu}$ materials for nitrate using hydrogen as reducer in a batch reactor. After 180 min reaction, the total removal rate for nitrate was $61.9 \%, 79.4 \%, 47.0 \%, 85.4 \%$, and $96.8 \%$ for Pd-Cu/HT2, Pd-Cu/HT3, Pd-Cu/HT4, Pd-Cu/HT5 and HT3 (Pd-Cu), respectively. The order of catalytic reduction capacity of these materials agreed well with the result of adsorption. Simultaneously, nitrite and ammonium ions were formed during the catalytic hydrogenation for nitrate. The highest selectivity for $\mathrm{N}_{2}$ was observed on HT3 $(\mathrm{Pd}-\mathrm{Cu})$. It indicated that different ratio of $\mathrm{Mg} / \mathrm{Al}$ and preparation method resulted in different adsorption and catalytic reduction capacity. Furthermore, the preparation method was a key influencing factor, and the material prepared by co-precipitation method showed the highest adsorption and catalytic reduction capacity, possibly due to different introduction method of active metals (Wang et al., 2007b).

Temperature and co-existed ions in water influence the adsorption and catalytic reduction capacity of hydrotalcitesupported Pd-Cu materials for nitrate (Wang et al., 2007b). Higher reaction temperature promoted the adsorption and catalytic reduction capacity of hydrotalcite-supported Pd$\mathrm{Cu}$ materials and simultaneously debased the accumulation of nitrite and ammonium. Co-existed cations in water with higher valence, and lower crystal ionic radius and solubility constant of hydroxide showed a stronger affinity toward $\mathrm{OH}^{-}$and consequently increased the concentration of active sites accessible to $\mathrm{NO}_{3}{ }^{-}$and $\mathrm{NO}_{2}{ }^{-}$. The competitive adsorption of $\mathrm{Cl}^{-}, \mathrm{SO}_{4}{ }^{2-}$, and $\mathrm{HCO}_{3}{ }^{-}$with nitrate on the surface of hydrotalcite-supported $\mathrm{Pd}-\mathrm{Cu}$ materials suppressed the adsorption and reduction of $\mathrm{NO}_{3}{ }^{-}$.

It was speculated that the nitrate removal on these materials, with $\mathrm{H}_{2}$ provided, was a consecutive and dynamic adsorption and catalytic hydrogenation process, as shown

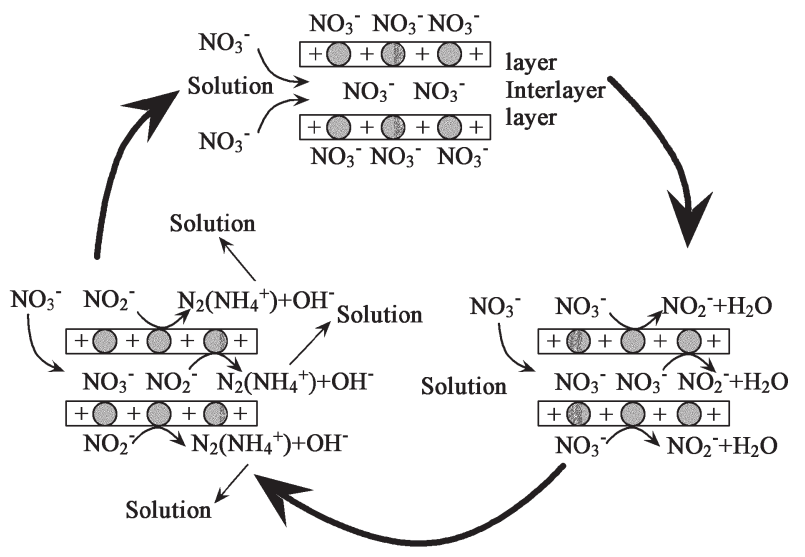

Fig. 2 A reaction scheme for the catalytic hydrogenation of nitrate on hydrotalcites-supported Pd-Cu catalysts (Wang et al., 2007b) in Fig.2 (Wang et al., 2007b). First, layer structure may be reconstructed once calcined hydrotalcite was put into nitrate solution. During this process, nitrate ions were adsorbed rapidly between the brucite-like layers and on the external surface by electrostatic force, resulting in high adsorption rate at the initial time. Then, adsorbed nitrate ions were reduced by $\mathrm{Pd} / \mathrm{Cu}$ active sites to nitrite ions, which were sequentially reduced to $\mathrm{N}_{2}$ or ammonium. The electroneutrality of the system was maintained by the $\mathrm{OH}^{-}$anions produced during the reduction process. Whereafter, hydrotalcite-supported $\mathrm{Pd}-\mathrm{Cu}$ materials may continuously adsorb nitrate ions through ion exchange with $\mathrm{OH}^{-}$, which was followed by the catalytic hydrogenation process. Therefore, the prepared hydrotalcite-supported $\mathrm{Pd}-\mathrm{Cu}$ materials may effectively combine the adsorption and catalytic reduction process, and thus exhibit a good potential for nitrate removal from water.

\section{Adsorption coupled with redox process}

Combining the oxidation and reduction effect in adsorption processes, some redox composite adsorbents have been developed and applied in water purification recently. It is a good example to remove arsenic from drinking water by using novel redox adsorbents.

In natural water, arsenic is primarily present in inorganic forms and exists in two predominant species, namely, arsenate $(\mathrm{As}(\mathrm{V}))$ and arsenite (As(III)). As (III) is much more toxic (Ferguson and Gavis, 1972), more soluble, more mobile, and more difficult to dispose than As(V). Various adsorbents including natural and synthetic materials are effective for As(V) (Driehaus et al., 1998) but fail in case of As(III) (Driehaus et al., 1994). To achieve higher arsenic removal, a pretreatment for As(III) oxidation is, therefore, usually involved followed by adsorption of the As(V) formed onto metal oxyhydroxides. However, the pretreatment increased not only running cost but also the complexity of operation. Besides, traditional oxidants such as chlorine, ozone, and hydrogen peroxide are not feasible for a specific oxidation of As(III) because of the side reactions with natural organic matter. So, the development of adsorbent that could simultaneously oxidize arsenite and adsorb the formed arsenate is becoming the focus of research (Chakravarty et al., 2002; Deschamps et al., 2005; Zhang and Itoh, 2006; Zhang et al., 2007b). Many composite adsorbents have been developed, and they can be mainly divided into the following two classes.

\section{1 $\mathrm{TiO}_{2}$-based composite adsorbents}

As mentioned above, titanium dioxide is an excellent photocatalytic material. Using titanium dioxide photocatalyst, the arsenite can be rapidly oxidized to arsenate. The oxidation mechanism of arsenite has been studied by several researchers and most of them believed that hydroxyl radicals are the dominant oxidants for arsenite oxidation (Dutta et al., 2005; Xu et al., 2005a). Moreover, titanium dioxide can also be used as a sorbent for arsenic removal (Bang et al., 2005; Pena et al., 2006). Bang and co-workers (2005) thoroughly investigated the adsorption 
performance of nano and granular titanium dioxide towards both arsenate and arsenite. They found that titanium dioxide had a relatively high adsorption capacity. But the arsenite removal by the $\mathrm{TiO}_{2}$ adsorbent was not effective as that of arsenate. Furthermore, the adsorption mechanism of arsenate and arsenite on the surface of $\mathrm{TiO}_{2}$ was also explained by using FT-IR spectroscopy and extended Xray absorption fine structure (EXAFS) spectroscopy and found that both $\mathrm{As}(\mathrm{V})$ and $\mathrm{As}(\mathrm{III})$ formed bidentate binuclear inner-sphere surface complexes (Pena et al., 2006).

However, the low adsorption capacity and separation problem of $\mathrm{TiO}_{2}$ powder from aqueous solution usually limit its application in contaminated water. In order to utilize the photocatalytic activity of $\mathrm{TiO}_{2}$ and the adsorption capacity of iron oxide sufficiently, Zhang and Itoh (2006) prepared a slag-iron oxide- $\mathrm{TiO}_{2}$ composite adsorbent by loading iron oxide and $\mathrm{TiO}_{2}$ on municipal solid waste melted slag for arsenite removal. The synthetic composite could rapidly oxidize arsenite to arsenate and simultaneously remove the arsenate from aqueous solution.

\section{2 $\mathrm{MnO}_{2}$-based composite adsorbents}

Manganese dioxide is an effective oxidizing agent of arsenite and is emphasized by some researchers (Oscarson et al., 1981; Stumm and Morgan, 1981). In addition, due to relatively low oxidation potential, $\mathrm{MnO}_{2}$ is a favorable oxidant for specific oxidation of arsenite. The redox reaction mechanism between manganese dioxide and arsenite has been investigated by some researchers (Scott and Morgan, 1995; Nesbitt et al., 1998; Manning et al., 2002). The works by Moore et al. (1990) and Nesbitt et al. (1998) demonstrated that the oxidation of As(III) by the synthetic birnessite surface proceeds by a two-step pathway, involving the reduction of $\mathrm{Mn}(\mathrm{IV})$ to $\mathrm{Mn}$ (III) and then $\mathrm{Mn}(\mathrm{III})$ to $\mathrm{Mn}(\mathrm{II})$.

Manganese dioxide can also be used as adsorbent for removal arsenic, but its adsorption capacity is commonly low (Lenoble et al., 2004) and this limits its application. To improve the removal efficiency, many composite adsorbents containing $\mathrm{MnO}_{2}$ have been synthesized. For examples, a manganese dioxide-coated sand (MDCS) adsorbent was prepared (Bajpai and Chaudhuri, 1999) by the oxidation of manganous ion by permanganate in the presence of sand. The MDCS showed a good removal performance for both arsenate and arsenite. Lenoble et al. (2004) achieved an $\mathrm{R}-\mathrm{MnO}_{2}$ adsorbent by loading manganese dioxide on a polystyrene resin matrix. The composite adsorbent had a markedly higher arsenic removal capacity than that of manganese dioxide. Besides, synthetic Fe oxide-coated $\mathrm{MnO}_{2}$ (Oscarson et al., 1983) has also been studied for the oxidation and sorption of As(III), but its As(III) adsorption capacity was lower than that of pure Fe oxide since $\mathrm{MnO}_{2}$ was coated by $\mathrm{Fe}$ oxide and could hardly oxidize As(III).

On the other hand, two natural Fe-Mn-mineral composite materials whose main components are $\mathrm{Fe}_{2} \mathrm{O}_{3}$ and $\mathrm{MnO}_{2}$ have been investigated as adsorbents for As(III) and As(V) removal from water (Chakravarty et al., 2002; Deschamps et al., 2005). Both of them are more effective for As(III) removal than that of As(V). They ascribed the higher As(III) uptake to the oxidation ability of manganese oxides content. However, their adsorption capacities for both $\mathrm{As}(\mathrm{III})$ and $\mathrm{As}(\mathrm{V})$ are low.

Recently, a novel Fe-Mn binary oxide composite adsorbent has successfully developed from low cost materials using a simultaneous oxidation and co-precipitation method for arsenic removal (Zhang et al., 2007b). This composite combined the oxidation property of manganese dioxide and the adsorption features to $\mathrm{As}(\mathrm{V})$ of iron (hydr)oxides which are well-known for their high affinity to arsenate and low cost (Pierce and Moore, 1982; Driehaus et al., 1998; Dixit and Hering, 2003). The composite was well characterized with a variety of techniques. It was found that this adsorbent had a high specific surface area and abundant surface hydroxyls. The test results exhibited that it had a high removal capacity towards both $\mathrm{As}(\mathrm{V})$ and As(III) and showed a significantly higher As(III) uptake than $\mathrm{As}(\mathrm{V})$. The maximal adsorption capacities for As(V) and As(III) were 0.93 and $1.77 \mathrm{mmol} / \mathrm{g}$, respectively. Fig.3

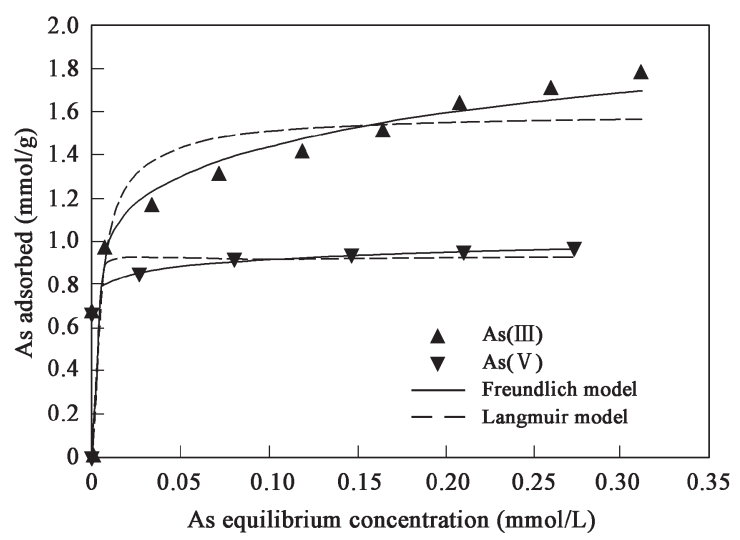

Fig. 3 Adsorption isotherms for As(III) and As(V) by Fe-Mn adsorbent in a $200 \mathrm{mg} / \mathrm{L}$ suspension at $\mathrm{pH} 5.0 \pm 0.1$ at low equilibrium As solution concentrations (Zhang et al., 2007b).

Table 2 Maximum arsenic adsorption capacities of some adsorbent system ${ }^{\mathrm{a}}$

\begin{tabular}{|c|c|c|c|}
\hline Adsorbent & $\begin{array}{l}\text { Max. As(III) adsorption } \\
\text { capacity }(\mathrm{mmol} / \mathrm{g})\end{array}$ & $\begin{array}{l}\text { Max. As }(\mathrm{V}) \text { adsorption } \\
\text { capacity }(\mathrm{mmol} / \mathrm{g})\end{array}$ & Reference \\
\hline Fe-Mn composite & $1.77(\mathrm{pH} 5.0)$ & $0.93(\mathrm{pH} 5.0)$ & Present study \\
\hline $\mathrm{MnO}_{2}$ & 0.13 & 0.1 & Lenoble et al., 2004 \\
\hline Goethite & - & $0.53(\mathrm{pH} \mathrm{3-3.3)}$ & Matis et al., 1997 \\
\hline $\mathrm{Al}_{2} \mathrm{O}_{3} / \mathrm{Fe}(\mathrm{OH})_{3}$ & $0.12(\mathrm{pH} 6.6)$ & $0.49(\mathrm{pH} 7.2)$ & Hlavay et al., 2005 \\
\hline Fe(III)-loaded sponge & $0.24(\mathrm{pH} 9.0)$ & $1.83(\mathrm{pH} 4.5)$ & Muñoz et al., 2002 \\
\hline Fe-Mn-mineral material & $0.16(\mathrm{pH} \mathrm{5.5)}$ & $0.09(\mathrm{pH} 5.5)$ & Deschamps et al., 20052005 \\
\hline $\mathrm{TiO}_{2}$ & $0.43(\mathrm{pH} 7.0)$ & $0.55(\mathrm{pH} 7.0)$ & Bang et al., 2005 \\
\hline
\end{tabular}

${ }^{\mathrm{a}} \mathrm{pH}$ is shown in parentheses. 
depicted this clearly (Zhang et al., 2007b). These results are favorable, compared with those obtained using other adsorbents (Table 2). Furthermore, to interpret the result of higher arsenite removal, the mechanism of As(III) removal by the Fe-Mn binary oxide adsorbent was well approved (Zhang et al., 2007c) and can be described as follows. As(III) was firstly transported to the solid-water interface by convection or diffusion from bulk solution. Then As(III) was adsorbed onto the surface by formation of surface complex. The adsorbed As(III) near the Mn atoms was oxidized into $\mathrm{As}(\mathrm{V})$ by $\mathrm{MnO}_{2}$ and the formed $\mathrm{As}(\mathrm{V})$ released into the solution with the reductive dissolution of $\mathrm{MnO}_{2}$. During this process, fresh active adsorption sites were formed at the solid surface. The As(V) was then transported to the solid-water interface and adsorbed onto the surface of the Fe-Mn adsorbent, occupying empty adsorption sites or replacing the sorptive As(III). The whole process can be briefly represented by reaction equations (1) $-(3)$.

$$
\begin{gathered}
\mathrm{As}(\mathrm{III})_{\mathrm{aq}}+\left(-\mathrm{S}_{\mathrm{Fe}-\mathrm{Mn}}\right) \longrightarrow \mathrm{As}(\mathrm{III})-\mathrm{S}_{\mathrm{Fe}-\mathrm{Mn}} \\
\mathrm{As}(\mathrm{III})-\mathrm{S}_{\mathrm{Fe}-\mathrm{Mn}}+\mathrm{MnO}_{2}+2 \mathrm{H}^{+} \longrightarrow \\
\mathrm{As}(\mathrm{V})_{\mathrm{aq}}+\mathrm{Mn}^{2+}+\mathrm{H}_{2} \mathrm{O} \\
\mathrm{As}(\mathrm{V})_{\mathrm{aq}}+\mathrm{As}(\mathrm{III})-\mathrm{S}_{\mathrm{Fe}-\mathrm{Mn}} \longrightarrow \\
\mathrm{As}(\mathrm{V})-\mathrm{S}_{\mathrm{Fe}-\mathrm{Mn}}+\mathrm{As}(\mathrm{III})_{\mathrm{aq}}
\end{gathered}
$$

where, $\left(-\mathrm{S}_{\mathrm{Fe}-\mathrm{Mn}}\right)$ represents an adsorption site on the $\mathrm{Fe}-\mathrm{Mn}$ adsorbent surface. As(III)- $\mathrm{S}_{\mathrm{Fe}-\mathrm{Mn}}$ represents the $\mathrm{As}(\mathrm{III})$ surface species and $\mathrm{As}(\mathrm{V})-\mathrm{S}_{\mathrm{Fe}-\mathrm{Mn}}$ represents the As(V) surface species. This process proceeded until As(III) or available $\mathrm{MnO}_{2}$ was depleted.

The formation of fresh adsorption sites at the solid surface during As(III) oxidation was attributed to the higher As(III) uptake.

In a summary, $\mathrm{TiO}_{2}$-based composite adsorbents can effectively oxidize arsenite and remove the formed arsenate in water treatment. However, the arsenite removal process still needs UV light to produce oxidants and this makes it not so convenient to operate. On the contrary, $\mathrm{MnO}_{2}$-based composite adsorbents, in particular the Fe-Mn binary oxide adsorbent, could effectively oxidize arsenite and adsorb the produced arsenate simultaneously. Therefore, the immobilization and practical application of $\mathrm{Fe}-\mathrm{Mn}$ composite materials may be a major research avenue in the arsenic removal.

\section{Biomimetic sorbent and its sorption behav- iors of persistent organic pollutants (POPs) in water}

Researches had shown that most hazardous vestigial POPs are especially difficult to be eliminated from water by activated carbon due to the lower concentration of POPs, from nanogram per liter to picogram per liter in water (Wang and Liu, 2001; Zhang et al., 2003). Consequently, it is attractive to develop novel sorbents to remove organic micropollutants from water efficiently.

Even at trace concentrations in water, POPs can accu- mulate in the lipid of organisms, such as white whales (Andersen et al., 2001), arctic wolves (Mary and Birgit, 1999), South African fur seals (Walter et al., 1999), marketable fish (Ahmed and Aly, 2004), and mussels (Azza et al., 2004; Perihan and Hulya, 2004). Using the concept of bioaccumulation, some researchers prepared biomimetic sorbent to remove POPs from water. Liu et al. (2005b) synthesized salmon milt DNA hydrogel beads as selective adsorbent of dioxins. Compared with normal adsorbents such as activated carbon and alumina, this DNA matrix showed a selective adsorptivity for the dioxin derivatives with planar structure such as dibenzo- $p$-dioxin, dibenzofuran, and biphenyl. Some researchers (Xu et al., 2005b; Ke et al., 2006) prepared a new type of composite membrane, triolein embedded-cellulose acetate membrane (TECAM), and used it in the uptake of six organochlorine pesticides. Results indicated that TECAM quickly and efficiently accumulated hydrophobic organochlorine pesticides (OCPs) from water. Semi-permeable membrane devices (SPMD), which are based on the diffusion of hydrophobic substances from water to membrane bags filled with lipophilic phases, are widely used for monitoring organic contaminants in water (Huckins et al., 1990; Lu et al., 2002; Lu and Wang, 2003; Frank, 2005). Recently, a novel composite absorbent, triolein-embedded sorbent, is proposed for selectively removing trace POPs from water (Ru et al., 2007a, 2007b; Huo et al., 2005a, 2005b; Liu et al., 2005a, 2007).

\subsection{Design and preparation of triolein-embedded sor- bent}

The designed structure of triolein-embedded sorbent is shown in Fig. 4. The sorbent either consists of the supporting materials and the surrounding triolein-embedded cellulose acetate membrane or prepares by embedding triolein into cellulose acetate (CA) spheres. Activated carbon and silicon gel granules were chosen as the supporting materials. The reasons for selecting triolein are that triolein has a high accumulation capacity $\left(10^{5}-10^{7}\right)$ for trace concentrations of POPs in water (Chiou, 1985) and it exhibits low membrane solubility and permeability because of its large molecular mass of 885.45 Da (Huckins et al., 1990). A cellulose acetate polymer was chosen for preparing hybrid materials because it can be easily molded into different forms such as membranes, fibers, and spheres. Furthermore, its hydrophilicity improves the

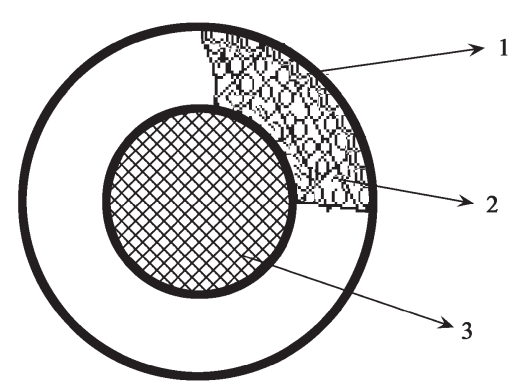

Fig. 4 Designed structure of triolein-embedded sorbent. 1: cellulose acetate membrane; 2 : triolein; 3 : supporting materials. 
accessibility of aqueous solutions to the surface of the film.

Three sorbents were produced which were composed of supporting activated carbon ( $\mathrm{Ru}$ et al., 2007a, 2007b) or silicon gel granules (Huo et al., 2005a, 2005b) and the surrounding triolein-embedded cellulose acetate membrane, or CA-triolein sphere (Liu et al., 2005a, 2007), respectively. The analysis results of SEM and XPS for the sorbent showed that the triolein was wrapped in the thin CA polymer and constituted a significant fraction of the lipid pool in the sorbent. Fluorescence test showed that triolein was fixed in the cellulose membrane tightly and no triolein had been detected in the water when using the sorbent for the water treatment.

\subsection{POPs removal efficiency by triolein-embedded sor- bent}

Dieldrin, endrin, aldrin, and heptachlor epoxide were chosen as model pollutants to test the sorption efficiency of triolein-embedded sorbent. Results showed that these pollutants could be removed by the CA-triolein absorbent effectively. When the initial concentration of these selective POPs was $1-10 \mu \mathrm{g} / \mathrm{L}$, nearly $90 \%$ of the POPs was removed after $1 \mathrm{~h}$ of sorption by the triolein-embedded sorbents. This suggests that triolein-embedded sorbent may serve as a good sorbent for those selected POPs. Triolein in the sorbent significantly increased the sorption capacity, and lower residual concentrations of POPs were achieved when compared to the use of cellulose acetate absorbent and granular activated carbon (GAC). Results also indicated that triolein-embedded sorbent appeared to be a promising sorbent with good selectivity for hydrophobic organic compounds, and the adsorption rate and removal efficiency for lipophilic POPs were positively related to their octanol-water partition coefficients $\left(\log K_{\text {ow }}\right)$. In addition, the sorbent also had satisfactory removal rate for lipophilic POPs from aqueous solutions when present in trace amounts.

A fixed-bed column experiment was also conducted to test the potential practical application. Results of the initial column experiments indicated that triolein-embedded sorbent had high removal efficiency for dieldrin when the influent concentration was $1-1.5 \mu \mathrm{g} / \mathrm{L}$ and the empty-bed contact time (EBCT) was $20 \mathrm{~min}$. It did not reach the breakthrough point $(0.1 \mu \mathrm{g} / \mathrm{L})$ at breakthrough empty-bed volumes of 4000 .

\subsection{Sorption behaviors of POPs on triolein-embedded sorbent}

The sorption isotherms of CA sorbent and trioleinembedded sorbent (CA-T), which using activated carbon as supporting material and GAC, were investigated using dieldrin as model pollutant. The results indicated that the experimental data fitted the Freundlich isotherm well in a range of initial concentrations from 1 to $50 \mu \mathrm{g} / \mathrm{L}$, and the correlation coefficients were between 0.994 and 0.998 , which is shown in Fig.5. The magnitude of $K_{\mathrm{F}}$ and $n$ values showed the easiest uptake of dieldrin and the highest equilibrium adsorptive capacity of CA-T.

The sorption of POPs on triolein-embedded sorbents has

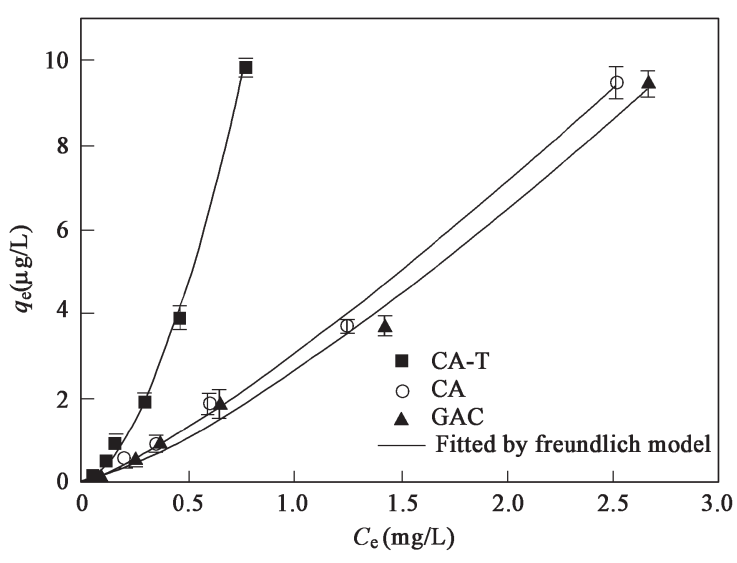

Fig. 5 Dieldrin adsorption isotherms at $25^{\circ} \mathrm{C}$ (Ru et al., 2006).

four steps. Organic pollutants were firstly adsorbed onto the surface of sorbents, then transferred into channels of $\mathrm{CA}$, and finally absorbed into the triolein. If there are supporting materials, the pollutants will be absorbed into the supporting materials.

The above sorption process can be proved by the intraparticle diffusion equation for bio-sorption systems, which is given by Weber and Morris (1963):

$q_{t}=k \times t^{0.5}$

where, $q_{t}$ is the amount of adsorbent at time $t(\mu \mathrm{g} / \mathrm{g})$ and $k$ is the rate constant $\left(\mu \mathrm{g} /\left(\mathrm{g} \cdot \mathrm{h}^{0.5}\right)\right)$.

The multilinear plots of $q_{t}$ vs. $t^{0.5}$ using the absorption results showed the intra-particle diffusion model for CAtriolein sphere sorbent. The order of absorption rate for the POPs follows the order $k_{1}>k_{2}>k_{3}$. In addition, the absorption rate for the four selected POPs has positive relation with the $\log K_{\text {ow }}$ of the chemicals.

The thermodynamic analysis of dieldrin sorption on triolein-embedded with experimental data of different temperatures was conducted. Thermodynamic parameters, such as change in free energy $\left(\Delta G^{0}\right)$, enthalpy $\left(\Delta H^{0}\right)$, and entropy $\left(\Delta S^{0}\right)$ were calculated from the variation of the thermodynamic equilibrium constant $K_{0}$ with the change in temperature. The calculation methods used were discussed in detail by Niwas et al. (2000). A positive value of $\Delta H^{0}$ indicated that the adsorption of dieldrin on CA-triolein sphere was endothermic. Since $\Delta G^{0}$ were negative and were accompanied by positive $\Delta S^{0}$, the reactions were spontaneous with high affinity for dieldrin (Matsui et al., 2003).

The results of the triolein-embedded sorbent showed that it is a promising sorbent for removal of the trace level POPs. These encouraging results will help in future work to address engineering issues for implementing the process on a larger scale.

\section{Modified adsorbents and their water purifi- cation efficiency}

Adsorbent which is modified by physical or chemical method could be recognized as modified adsorbent. Actually, almost all the adsorbents can be modified to 
enhance the adsorption capacity and the efficiency in water treatment. Modified adsorbents are, therefore, various, and the number is tremendous. For example, several tens of carbon-based modified adsorbents from granular activated carbon, powdered activated carbon, and carbon nanotube can be found in the literature. Here, we would like to emphasize the magnetic particles modified adsorbents because these adsorbents can be easily prepared and utilized in the water purification. The main aim of developing such adsorbents is to integrate two separate phases for enhanced separation. In brief, these adsorbents may be classified as three categories, according to the difference of the support of magnetic particles.

\subsection{Surface modified $\mathrm{Fe}_{3} \mathrm{O}_{4}$ adsorbent}

Magnetite is one of the most common and important magnetic materials. As a magnetic particle, it can be easily integrated with other adsorbents to produce magnetic composite adsorbent for water purification. But commercially available $\mathrm{Fe}_{3} \mathrm{O}_{4}$ is usually poor in adsorption properties, except for nano-scale one.

To enhance the adsorption capacity of commercial $\mathrm{Fe}_{3} \mathrm{O}_{4}, \mathrm{Wu}$ and $\mathrm{Qu}$ (2004) modified it by the precipitate of $\mathrm{Fe}$ (III) hydroxide on the surface without affecting its magnetism property. Acid Red B was selected as a model organic compound for adsorption test in the study. The results showed that the specific surface area and the adsorption capacity of modified $\mathrm{Fe}_{3} \mathrm{O}_{4}$ for Acid Red $\mathrm{B}$ significantly increased. Besides, the regeneration of saturated sorbent by oxidation using Fenton's reagent was investigated. They found the modified magnetite could be well regenerated even with a higher adsorption capacity and be used repeatedly.

\subsection{Magnetic-particle-modified carbon adsorbent}

The powdered activated carbon not only has high adsorption rate and capacity for various organic pollutants but is inexpensive. However, it is difficult to separate it from aquatic phase because of its small size. The traditional filtration method could cause the blockage of filters. Therefore, powdered activated carbon has been traditionally discarded with the process sludge after using it in water treatment (Clifford et al., 1983).

Recently, the synthesis of magnetic carbon adsorbent by integrating magnetic particles with powdered activated carbon has gained increasing attention from a good many of researchers worldwide. A series of activated carbon/magnetic particle composites have been prepared. And several methods such as impregnation (Wang et al.,
1994; Gorria et al., 2006), ball milling (Rudge et al., 2000), and chemical co-precipitation (S̆afařík et al., 1997; Oliveira et al., 2002) have been developed. Among these methods, chemical co-precipitation is the most promising one because it is simple and no special chemicals and procedures are needed.

The most frequently used magnetic particle is iron oxide, especially magnetite. Researchers (Šafař́k et al., 1997; Oliveira et al., 2002) have successfully prepared activated carbon/iron oxide magnetic composites, which could be used to remove a wide range of organic pollutants and be separated by magnetic separation technology conveniently. Gorria et al. (2006) synthesized a magnetic activated carbon containing nickel nanoparticles within the porous network. The magnetic composite obtained exhibits a large surface area and a high pore volume. In addition, Peng et al. (2005) prepared a carbon nanotube-iron oxides magnetic composite and tested the adsorption of $\mathrm{Pb}$ (II) and $\mathrm{Cu}$ (II) from water. The findings reveal that the composite adsorbent has high effectiveness for metal ion removal. However, these studies mainly focused on how to make activated carbon magnetic but no regeneration of the spent magnetic composites was involved.

To combine the high adsorption capacity of activated carbon with the magnetic and excellent catalytic properties of powdered $\mathrm{CuFe}_{2} \mathrm{O}_{4}$, Zhang et al. (2007a) synthesized a novel magnetic $\mathrm{CuFe}_{2} \mathrm{O}_{4}$ /activated carbon composite adsorbent using a chemical co-precipitation method. The characteristics such magnetization and BET surface area of the obtained adsorbent were determined. The results indicate that the composite was magnetic and the presence of $\mathrm{CuFe}_{2} \mathrm{O}_{4}$ did not significantly affect the surface area and pore structure of the activated carbon. This can be confirmed by the data listed in Table 3. Besides, the adsorption of azo dye Acid Orange II on the adsorbents was examined by batch tests. Interestingly, no reduction in adsorption capacity was produced by the formation of the composite when used to adsorb Acid Orange II from water, compared with original activated carbon. The adsorption isotherm in Fig.6 can exhibit this result (Zhang et al., 2007a). Furthermore, the decomposition process of Acid Orange II adsorbed on the surface of activated carbon and the composite in an inert atmosphere was studied by the authors using in situ FTIR technique. The results indicated that the $\mathrm{CuFe}_{2} \mathrm{O}_{4}$ particles could effectively catalyze the thermal pyrolysis of Acid Orange II. The results of regeneration tests suggested that the most adsorption capacity of the composite adsorbent was re-established after thermal treatment and it could be used for several recycles.

Table 3 Magnetization, BET surface area and microporosity measurements for the $\mathrm{CuFe}_{2} \mathrm{O}_{4} /$ activated carbon composites (Zhang et al., 2007)

\begin{tabular}{lllll}
\hline Composite & $\begin{array}{l}\mathrm{CuFe}_{2} \mathrm{O}_{4} \\
(\mathrm{wt} . \%)\end{array}$ & $\begin{array}{l}\text { Specific saturation } \\
\text { magnetization }(\mathrm{emu} / \mathrm{g})\end{array}$ & $\begin{array}{l}\mathrm{BET} \text { surface } \\
\text { area }\left(\mathrm{m}^{2} / \mathrm{g}\right)\end{array}$ & $\begin{array}{l}\text { Micro-pore } \\
\text { volume }\left(\mathrm{cm}^{3} / \mathrm{g}\right)\end{array}$ \\
\hline Pure activated carbon & 0 & 0 & 799 & 0.229 \\
Composite $1: 2$ & 33 & 0.97 & $558\left(794^{*}\right)$ & $0.153\left(0.223^{*}\right)$ \\
Composite $1: 1.5$ & 40 & 2.30 & $549\left(857^{*}\right)$ & $0.144\left(0.231^{*}\right)$ \\
Composite $1: 1$ & 50 & 5.93 & $488\left(889^{*}\right)$ & $0.118\left(0.223^{*}\right)$ \\
$\mathrm{CuFe}_{2} \mathrm{O}_{4}$ & -100 & 22.5 & 87 & 0.013 \\
\hline
\end{tabular}

*expressed on activated carbon mass basis. 

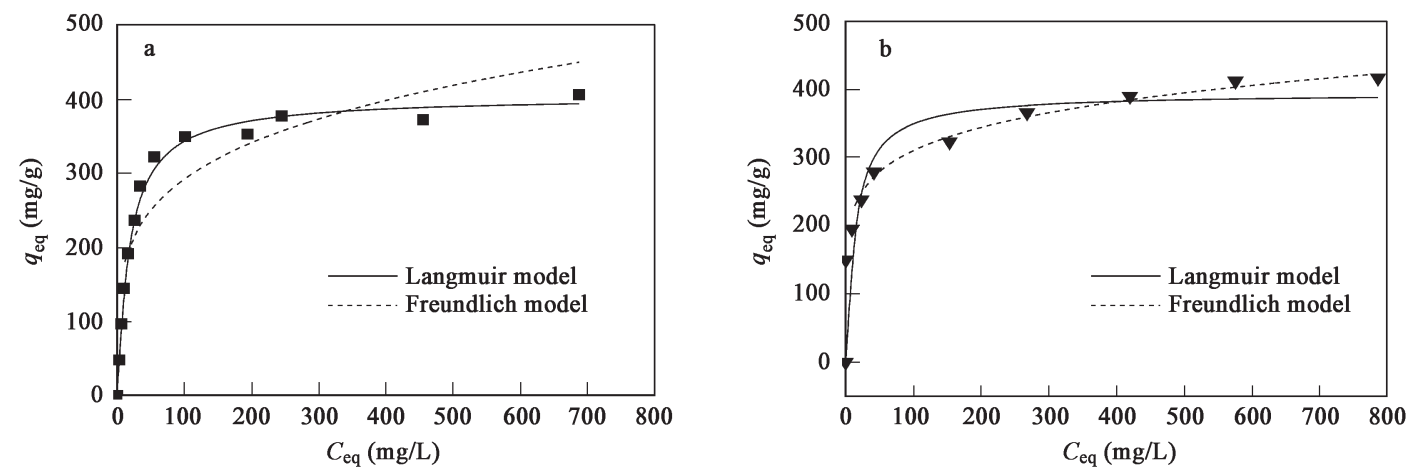

Fig. 6 Adsorption isotherm for Acid Orange 7 (AO7) on (a) original activated carbon and (b) the 1:1.5 composite. (50 ml AO7 solution, initial concentrations up to $1200 \mathrm{mg} / \mathrm{L}, \mathrm{pH} 5.2 \pm 0.1 ; 25 \pm 1^{\circ} \mathrm{C} ; 0.100 \mathrm{~g}$ adsorbent).

\subsection{Magnetic-particles-modified clay mineral adsor- bent}

As a kind of low-cost and readily available materials, clay minerals have excellent cation exchange properties and are often used to adsorb metallic contaminants in the water treatment. The adsorption capacity of clays results from a relatively high surface area and a net negative charge on their structure. But the smaller particle size of the clays make them difficult to separate from water phase like the powdered activated carbon.

To separate the clay adsorbents conveniently, Oliveira et al. (2003, 2004) combined iron oxide with clay minerals and achieved two kinds of magnetic particle modified adsorbents, namely, bentonite-iron oxide and zeolite-iron oxide magnetic adsorbents. The adsorbents obtained both have good magnetic property. The adsorption of metal ions such as $\mathrm{Ni}^{2+}, \mathrm{Cu}^{2+}$, and $\mathrm{Cd}^{2+}$ by the magnetic composites from aqueous solutions was studied. The results show that they are effective in metal ion removal.

\subsection{Magnetic-particle-modified biopolymer adsorbent}

Biopolymers such as chitin and alginate are common and readily available materials. In terms of abundance, chitin is the second biopolymer after cellulose in nature. Alginate can be abundantly extracted from various species of brown seaweed.

These polymers and their derivatives have excellent adsorption performance because of the presence of a great number of active functional groups (acetamido, primary amino and/or hydroxyl groups) (Crini, 2005). Besides, they have many advantages including being low-cost, widely available in many countries, renewable, and modifiable. They also have biological and chemical properties such as nontoxicity, biocompatibility, and biodegradability. In spite of these properties and advantages, some problems still exist. They are often used as powder forms, which are difficult to separate from water or may cause a significant pressure drop in the column.

Making these biopolymers magnetic by integrating magnetic particles with them may efficiently solve these problems. Therefore, many magnetic biopolymers have been synthesized and used as adsorbents for removal of contaminants in the recent years. Chang et al. (2005a, 2005 b, 2006) fabricated a chitosan-bound $\mathrm{Fe}_{3} \mathrm{O}_{4}$ magnetic adsorbent by the covalent binding of carboxymethylated chitosan on $\mathrm{Fe}_{3} \mathrm{O}_{4}$ nanoparticles via carbodiimide activation. The analysis results indicated that the chitosanbound $\mathrm{Fe}_{3} \mathrm{O}_{4}$ nanoparticles were monodisperse with a mean diameter of $13.5 \mathrm{~nm}$, and the binding of chitosan did not change the spinel structure of $\mathrm{Fe}_{3} \mathrm{O}_{4}$. They also investigated the adsorption of $\mathrm{Cu}^{2+}, \mathrm{Co}^{2+}$, and acid dyes of Crocein Orange G (AO12) and Acid Green 25 (AG25) on the magnetic adsorbent from the solution. They found that the adsorption rate was quite fast and the maximal adsorption capacities for $\mathrm{Cu}^{2+}, \mathrm{Co}^{2+}, \mathrm{AO} 12$ and $\mathrm{AG} 25$ were $21.5,27.5,1883$ and $1471 \mathrm{mg} / \mathrm{g}$, respectively. Such fast adsorption rate and adsorption capacity were ascribed to the absence of internal diffusion resistance and the high specific surface area. Ma et al. (2007) also prepared the magnetic chitosan adsorbent by a co-precipitation method. This adsorbent was tested for the removal of fluoride from water in batch systems and an adsorption capacity of 20.96-23.98 mg/g was achieved. In addition, they studied the regeneration of the exhausted adsorbent using $0.8 \%-$ $1 \% \mathrm{NaOH}$ washing water. Donia et al. (2007) synthesized a chemically modified magnetic chitosan adsorbent. The obtained adsorbent was tested for the recovery of $\mathrm{Au}$ (III) and $\operatorname{Ag}(\mathrm{I})$ from their aqueous solutions using batch and column methods. Uptake values of 3.6 and $2.1 \mathrm{mmol} / \mathrm{g}$ were reported for $\mathrm{Au}(\mathrm{III})$ and $\mathrm{Ag}(\mathrm{I})$, respectively.

A magnetic alginate microcapsule containing an extractant of Cyanex 272 was achieved by Ngomsik and co-workers and was used as adsorbent for the heavy metal nickel(II) removal from water. The results of batch adsorption tests demonstrated that the maximal uptake of $\mathrm{Ni}^{2+}$ was $0.52 \mathrm{mmol} / \mathrm{g}$ (Ngomsik et al., 2006). Lim and Chen (2007) prepared a calcium-alginate magnetic sorbent using an electrostatic extrusion technique and tested it for removal of copper ions and arsenate. The maximal capacities of arsenate and copper ions are 6.75 and $60.24 \mathrm{mg} / \mathrm{g}$. In order to selectively remove organic compounds from wastewater, alginate beads containing magnetic nanoparticles and activated carbon (AC-MAB) were prepared (Rocher et al., 2007). Two dyes, Methylene Blue (MB) and Methyl Orange (MO), were chosen as models of pollutant for test and found that the magnetic composite had a quite higher adsorption capacity to methylene blue, compared with pure carbon. 
In summary, the modification of adsorbent with magnetic particles may represent an important and promising approach to produce magnetic composite which can be easily separated and is attracting more and more attentions from researchers worldwide.

\section{Conclusions}

To obtain the anticipated function and enhance the efficiency of water purification, adsorbents can be designed and modified in their compositions, structures, surfaces, and preparation methods. These kinds of adsorbents can possess their special physical, chemical, and biological properties and exhibit some peculiar behaviors in the reactions, transformation, and removal of contaminants in water. In fact, the ability and efficiency of the adsorption technologies in water treatment also depend on the characteristics and functions of adsorbents. Therefore, to transfer the species of pollutants for promoting the adsorption rate, we can design and prepare some special composite adsorbents with the redox, catalytic, and adsorptive functions which can carry out the processes of oxidation/reduction and adsorption of pollutants synchronously. In order to eliminate some trace concentration of organic substances in water, we can synthesize some biomimetic sorbents and develop the corresponding technologies for water purification. In addition, according to the water quality modifying some applied adsorbents, such as active carbon, no doubt is a very significant way to enhance the efficiency of water treatment processes.

\section{Acknowledgements}

This work was supported by the Natural Science Foundation of China (No. 50538090). The author also thanks Dr. Zhang Gaosheng, Liu Huijuan, and Wang Ying for their valuable contribution for this article.

\section{References}

Abollino O, Aceto M, Malandrino, Sarzanini C, Mentasti E, 2003. Adsorption of heavy metals on Na-montmorillonite effect of pH and organic substances. Water Res, 37: 16191627.

Ahmed E N, Aly M A A, 2004. Organochlorine contamination in some marketable fish in Egypt. Chemosphere, 54: 14011406.

Andersen G, Kovacs K M, Lydersen C, Skaare J U, Gjertz I, Jenssen B M, 2001. Concentrations and patterns of organochlorine contaminants in white whales (Delphinapterus leucas) from Svalbard, Norway. The Science of the Total Environment, 264: 267-281.

Anderson C, Bard A J, 1995. An improved photocatalyst of $\mathrm{TiO}_{2} / \mathrm{SiO}_{2}$ prepared by a sol-gel synthesis. J Phys Chem, 99: 9882-9885.

Anderson C, Bard A J, 1997. Improved photocatalytic activity and characterization of mixed $\mathrm{TiO}_{2} / \mathrm{SiO}_{2}$ and $\mathrm{TiO}_{2} / \mathrm{Al}_{2} \mathrm{O}_{3}$ materials. J Phys Chem B, 101: 2611-2616.

Atia A A, Donia A M, Abou-El-Enein S A, Yousif A M, 2003. Studies on uptake behavior of copper(II) and lead(II) by amine chelating resins with different textural properties. Sep Purif Technol, 33: 295-301.

Azza K, Ahmed E N, Tarek O S, Amany E S, Aly M A A, 2004. Polychlorinated biphenyls and chlorinated pesticides in mussels from the Egyptian Red Sea coast. Chemosphere, 54: 1407-1412.

Babel S, Kurniawan T A, 2003. Low-cost adsorbents for heavy metals uptake from contaminated water: a review. $J$ Hazardous Mat, 97: 219-243.

Bajpai S, Chaudhuri M, 1999. Removal of arsenic from ground water by manganese dioxide-coated sand. Journal of Environmental Engineering, 125(8): 782-784.

Bang S, Patel M, Lippincott L, Meng X, 2005. Removal of arsenic from groundwater by granular titanium dioxide adsorbent. Chemosphere, 60: 389-397.

Bhattacharyya A, Kawi S, Ray M B, 2004. Photocatalytic degradation of Orange II by $\mathrm{TiO}_{2}$ catalysts supported on adsorbents. Catalysis Today, 98: 431-439

Bouraada M, Lafjah M, Ouali M S, Menorval L C, 2007. Basic dye removal from aqueous solutions by dodecylsulfateand dodecyl benzene sulfonate-intercalated hydrotalcite. Journal of Hazardous Materials (in press).

Cavani F, Trifiro F, Vaccari A, 1991. Hydrotalcite-type anionic clays: preparation, properties and applications. Catalysis Today, 11: 173-301.

Celis R, Carmen H M, Cornejo J, 2000. Heavy metal adsorption by functionalized clays. Environ Sci Technol, 34: 45934599.

Chakravarty S, Dureja V, Bhattacharyya G, Maity S, Bhattacharjee $S, 2002$. Removal of arsenic from groundwater using low cost ferruginous manganese ore. Water Res, 36: 625632.

Chang C T, Liaw B J, Huang C T, Chen Y Z, 2007. Preparation of $\mathrm{Au} / \mathrm{Mg}_{x} \mathrm{AlO}$ hydrotalcite catalysts for $\mathrm{CO}$ oxidation. Applied Catalysis A: General, 332(2): 216-224.

Chang Y C, Chen D H, 2005a. Preparation and adsorption properties of monodisperse chitosan-bound $\mathrm{Fe}_{3} \mathrm{O}_{4}$ magnetic nanoparticles for removal of $\mathrm{Cu}(\mathrm{II})$ ions. Journal of Colloid and Interface Science, 283(2): 446-451.

Chang Y C, Chen D H, 2005b. Adsorption kinetics and thermodynamics of acid dyes on a carboxymethylated chitosanconjugated magnetic nano-adsorbent. Macromolecular Bioscience, 5(3): 254-261.

Chang Y C, Chang S W, Chen D H, 2006. Magnetic chitosan nanoparticles: Studies on chitosan binding and adsorption of Co(II) ions. Reactive and Functional Polymers, 66: 335341.

Chiou C T, 1985. Partition coefficients of organic compounds in lipid-water systems and correlations with fish bioconcentration factors. Environ Sci Technol, 19: 57-62.

Clifford D, Chu P, Lau A, 1983. Thermal regeneration of powdered activated carbon (PAC) and PAC-biological sludge mixtures. Water Res, 17: 1125-1138.

Crini G G, 2005. Recent developments in polysaccharide-based materials used as adsorbents in wastewater treatment. Prog Polym Sci, 30: 38-70.

Deschamps E, Ciminelli V S T, Höll W H, 2005. Removal of $\mathrm{As}(\mathrm{III})$ and $\mathrm{As}(\mathrm{V})$ from water using a natural $\mathrm{Fe}$ and $\mathrm{Mn}$ enriched sample. Water Res, 39(20): 5212-5220.

Dixit S, Hering J G, 2003. Comparison of $\operatorname{arsenic}(V)$ and arsenic(III) sorption onto iron oxide minerals: implications for arsenic mobility. Environ Sci Technol, 37: 4182-4189.

Donia A M, Atia A A, Elwakeel K Z, 2007. Recovery of gold(III) and silver(I) on a chemically modified chitosan 
with magnetic properties. Hydrometallurgy, 87(3-4): 197206.

Driehaus W, Jekel M, Hildebrandt U, 1998. Granular ferric hydroxide-a new adsorbent for the removal of arsenic from natural water. $J$ Water SRT-Aqua, 47: 1-6.

Driehaus W, Seith R, Jekel M, 1994. Oxidation of arsenite(III) with manganese oxides in water treatment. Water Res, 29(1): 297-305.

Dutta P K, Pehkonen S O, Sharma V K, Ray A K, 2005. Photocatalytic oxidation of Arsenic(III): Evidence of hydroxyl radicals. Environ Sci Technol, 39(6): 1827 -1834.

Ferguson J F, Gavis J, 1972. A review of the arsenic cycle in nature waters. Water Res, 6: 1259-1274.

Frank S L, 2005. Review of passive accumulation devices for monitoring organic micropollutants in the aquatic environment. Environ Pollut, 136: 503-524.

Gorria P, Sevilla M, Blanco J A, Fuertes A B, 2006. Synthesis of magnetically separable adsorbents through the incorporation of protected nickel nanoparticles in an activated carbon. Carbon, 44: 1954-1957.

Gu Z, Fang J, Deng B L, 2005. Preparation and evaluation of GAC-based iron-containing adsorbents for arsenic removal. Environ Sci Technol, 39: 3833-3843.

Huckins J N, Tubergen, M W, Manuweera G K, 1990. Semipermeable membrane devices containing model lipid: a new approach to monitoring the bioavailability of lipophilic contaminants and estimating their bioconcentration potentiall. Chemosphere, 20: 533-552.

Huo J X, Liu H J, Qu J H, Wang Z J, Ge J T, Liu H N, 2005a. Preparation and characteristic of triolein-embedded composite sorbents for water purification. Separation and Purification Technology, 44: 37-43.

Huo J X, Liu H J, Qu J H, Ru J, Liu H N, Li G T, 2005b. Dieldrin and endrin removal from water by triolein-embedded adsorbent. Chinese Science Bulletin, 50(3): 2696-2700

Ke R H, Xu Y P, Wang Z J, Khan S U, 2006. Estimation of the uptake rate constants for polycyclic aromatic hydrocarbons accumulated by semipermeable membrane devices and triolein-embedded cellulose acetate membranes. Environ Sci Technol, 40: 3906-3911.

Kuzawa K, Jung Y J, Kiso Y, Yamada T, Nagai M, Lee T G, 2006. Phosphate removal and recovery with a synthetic hydrotalcite as an adsorbent. Chemosphere, 62(1): 45-52.

Laurin V, Labb N, Juteau P, Parent S, Villemur R, 2006. Long-term storage conditions for carriers with denitrifying biomass of the fluidized, methanol-fed denitrification reactor of the Montreal Biodome, and the impact on denitrifying activity and bacterial population. Water Research, 40(9): 1836-1840.

Lenoble V, Laclautre C, Serpaud B, Deluchat V, Bollinger J C, 2004. As(V) retention and As(III) simultaneous oxidation and removal on a $\mathrm{MnO}_{2}$-loaded polystyrene resin. Sci Total Environ, 326: 197-207.

Lepore G P, Persaud L, Langford C H, 1996. Supporting titanium dioxide photocatalysts on silica gel and hydrophobically modified silica gel. J Photochem Photobiol A: Chem, 98: 103-111.

Lim S F, Chen J P, 2007. Synthesis of an innovative calciumalginate magnetic sorbent for removal of multiple contaminants. Applied Surface Science, 253: 5772-5775.

Liu H J, Dai R H, Qu J H, 2005a. Preparation and characterization of a novel adsorbent for removing lipophilic organic from water. Science in China (Series B), 48(6): 600-604.

Liu H J, Qu J H, Dai R H, Ru J, Wang Z J, 2007. A biomimetic absorbent for removal of trace level persistent organic pollutants from water. Environmental Pollution, 147: 337 342.

Liu X D, Murayama Y, Matsunaga M, Nomizu M, 2005 b. Preparation and haracterization of DNA hydrogel bead as selective adsorbent of dioxins. International Journal of Biological Macromolecules, 35: 193-199.

Loukidou M X, Matis K A, Zouboulis A I, LiakopoulouKyriakidou M, 2003. Removal of As(V) from wastewaters by chemically modified fungal biomass. Water Res, 37: 4544-4552.

Lu Y B, Wang Z J, Huckins J, 2002. Review of the background and application of CA-triolein semipermeable membrane devices in aquatic environmental study. Aquatic Toxicology, 60: 139-153.

Lu Y B, Wang Z J, 2003. Accumulation of organochlorinated pesticides by CA-triolein semipermeable membrane device (triolein-SPMD) and rainbow trout. Water Res, 37: 24192425.

Ma W, Ya F Q, Han M, Wang R, 2007. Characteristics of equilibrium, kinetics studies for adsorption of fluoride on magnetic-chitosan particle. Journal of Hazardous Materials, 143(1-2): 296-302.

Machado L C R, Lima F W J, Paniago R, 2006a. Polymer coated vermiculite-iron composites: Novel floatable magnetic adsorbents for water spilled contaminants. Applied Clay Science, 31: 207-215.

Machado L C R, Torchia C B, Lago R M, 2006b. Floating photocatalysts based on $\mathrm{TiO}_{2}$ supported on high surface area exfoliated vermiculite for water decontamination. Catalysis Communications, 7: 538-541.

Maia M P, Rodrigues M A, Passos F B, 2007. Nitrate catalytic reduction in water using niobia supported palladium-copper catalysts. Catalysis Today, 123(1-4): 171-176.

Manning B A, Fendorf S E, Bostick B, Suarez D L, 2002. Arsenic(III) oxidation and arsenic(V) adsorption reactions on synthetic birnessite. Environ Sci Technol, 36: 976-981.

Mary G, Birgit M B, 1999. Contaminant residue levels in arctic wolves (Canis lupus) from the Yukon Territory, Canada. The Science of the Total Environment, 243: 329-338.

Moore J N, Walker J R, Hayes T H, 1990. Reaction scheme for the oxidation of $\mathrm{As}(\mathrm{III})$ to $\mathrm{As}(\mathrm{V})$ by birnessite. Clays and Clay Minerals, 38 (5): 549-555.

Nesbitt H W, Canning G W, Bancroft G M, 1998. XPS study of reductive dissolution of $7 \AA$-birnessite by $\mathrm{H}_{3} \mathrm{AsO}_{3}$ with constraints on reaction mechanism. Geochim Cosmochim Acta, 62(12): 2097-2110.

Ngomsik A F, Bee A, Siaugue J M, Cabuil V, Cote G, 2006. Nickel adsorption by magnetic alginate microcapsules containing an extractant. Water Res, 40: 1848-1856.

Niwas R, Gupta U, Khan A A, Varshney K G, 2000. The adsorption of phosphamidon on the surface of styrene supported zirconium(IV) tungstophosphate: a thermodynamic study. Colloids Surfaces A, 164: 115-119.

Nouri S, Haghseresht F, Lu G Q M, 2002. Comparison of adsorption capacity of p-cresol \& p-nitrophenol by activated carbon in single and double solute. Adsorption, 8: 215-223.

Oliveira L C A, Rios R R A, Fabris J D, Garg V, Sapag K, Lago R $\mathrm{M}, 2002$. Activated carbon/iron oxide magnetic composites for the adsorption of contaminants in water. Carbon, 40: 2177-2183.

Oliveira L C A, Rios R V R A, Fabris J D, Sapag K, Garg V K, Lago R M, 2003. Clay-iron oxide magnetic composites for the adsorption of contaminants in water. Applied Clay 
Science, 22: 169-177.

Oliveira L C A, Petkowicz D I, Smaniotto A, Pergher S B C, 2004. Magnetic zeolites: a new adsorbent for removal of metallic contaminants from water. Water Res, 38: 36993704.

Orthman J, Zhu H Y, Lu G Q, 2007. Use of anion clay hydrotalcite to remove coloured organics from aqueous solutions. Separation and Purification Technology, 31(1): 53-59.

Oscarson D W, Huang P M, Defosse C, Herbillon A, 1981. Oxidative power of $\mathrm{Mn}(\mathrm{IV})$ and $\mathrm{Fe}(\mathrm{III})$ oxides with respect to As(III) in terrestrial and aquatic environments. Nature, 291: $50-51$.

Oscarson D W, Huang P M, Hammer U T, 1983. Oxidation and sorption of arsenite by manganese dioxide as influenced by surface coatings of iron and aluminum oxides and calcium carbonate. Water, Air, and Soil Pollution, 20: 233-244.

Parida K M, Baliarsingh N, Sairam Patra B, Das J, 2007. Copperphthalocyanine immobilized $\mathrm{Zn} / \mathrm{Al} \mathrm{LDH}$ as photocatalyst under solar radiation for decolorization of methylene blue. Journal of Molecular Catalysis A: Chemical, 267(1-2): 202-208.

Pena M, Meng X, Korfiatis G P, Jing C, 2006. Adsorption mechanism of arsenic on nanocrystalline titanium dioxide. Environ Sci Technol, 40(4): 1257-1262.

Peng X J, Luan Z K, Di Z C, Zhang Z G, Zhu C L, 2005. Carbon nanotubes-iron oxides magnetic composites as adsorbent for removal of $\mathrm{Pb}(\mathrm{II})$ and $\mathrm{Cu}(\mathrm{II})$ from water. Carbon, 43: 855-894.

Peng X J, Luan Z K, Zhang H M, 2006. Montmorillonite$\mathrm{Cu}(\mathrm{II}) / \mathrm{Fe}$ (III) oxides magnetic material as adsorbent for removal of humic acid and its thermal regeneration. Chemosphere, 63: 300-306.

Pereira M F R, Soares S F, Orfao J J M, Figueiredo J L, 2003. Adsorption of dyes on activated carbons: influence of surface chemical groups. Carbon, 41: 811-821.

Perihan B K, Hulya B O, 2004. A survey to determine levels of chlorinated pesticides and PCBs in mussels and seawater from the Mid-Black Sea Coast of Turkey. Marine Pollution Bulletin, 48: 1076-1083.

Pierce M L, Moore C B, 1982. Adsorption of arsenite and arsenate on amorphous iron hydroxide. Water Res, 16: $1247-1253$.

Robinson T, Chandran B, Nigam P, 2002. Removal of dyes from a synthetic textile dye effluent by biosorption on apple pomace and wheat straw. Water Res, 36: 2824-2830.

Rocher V, Siaugue J M, Cabuil V, Bee A, 2007. Removal of organic dyes by magnetic alginate beads. Water Res (in press).

Ru J, Liu H J, Qu J H, Wang A M, Dai R H, Wang Z J, 2007a. Selective removal of OCPs from aqueous solution by triolein-embedded composite adsorbent. J Environ Sci Health, B42(1): 1-9.

Ru J, Liu H J, Qu J H, Wang A M, Dai R H, 2007b. Removal of dieldrin from aqueous solution by a novel trioleinembedded composite adsorbent. J Hazard Mater, 141: 61-69.

Rudge S R, Kurtz T L, Vessely C R, Catterall L G, Williamson D L, 2000. Preparation, characterization, and performance of magnetic iron-carbon composite microparticles for chemotherapy. Biomaterials, 21: 1411-1420.

Šafařík I, Nymburská, Šafaříková M, 1997. Adsorption of watersoluble organic dyes on magnetic charcoal. J Chem Tech Biotechnol, 69: 1-4.

Sampath S, Uchida H, Yoneyama H, 1994. Photocatalytic degra- dation of gaseous pyridine over zeolite-supported titanium dioxide. Journal of Catalysis, 149(1): 189-194.

Sasaki S, Aisawa S, Hirahara H, Sasaki A, Nakayama H, Narita E, 2006. Synthesis of p-sulfonated calix[4]areneintercalated layered double hydroxides and their adsorption properties for organic molecules. Journal of the European Ceramic Society, 26(4-5): 655-659.

Scott M J, Morgan J J, 1995. Reactions at oxide surfaces. 1. oxidation of As(III) by synthetic birnessite. Environ Sci Technol, 29: 1898-1905.

Silverio F, Reis M J, Tronto J, Valim J B, 2007. Removal of aliphatic amino acids by hybrid organic-inorganic layered compounds. Applied Surface Science, 253(13): 5756-5761.

Stumm W and Morgan J J, 1981. Aquatic Chemistry. Wiley, New York.

Takeda N, Ohtani M, Torimoto T, Kuwabata S, Yoneyama H, 1997. Evaluation of diffusibility of adsorbed propionaldehyde on titanium dioxide-loaded adsorbent photocatalyst films fromits photodecomposition rate. J Phys Chem B, 101: 2644-2649.

Torimoto T, Okawa Y, Takeda N, Yoneyama H, 1997. Effect of activated carbon content in $\mathrm{TiO}_{2}$-loaded activated carbon on photodegradation behaviors of dichloromethane. J Photochem Photobiol A: Chem, 103(1-2): 153-157.

Walter V, Marion W, Elke S, Bernd L, Herbert O, 1999. Levels of organochlorines (DDT, PCBs, toxaphene, chlordane, dieldrin, and HCHs) in blubber of South African fur seals (Arctocephalus pusillus pusillus) from Cape Cross/Namibia. Marine Pollution Bulletin, 38: 830-836.

Wang C L, Liu Q C, Cheng X Z, 1994. Adsorption and desorption of gold on the magnetic activated carbon. J Mater Sci Technol, 10: 151-153.

Wang Z S, Liu W J, 2001. Drinking water treatments for micropollutant water resources. Beijing: China Architecture \& Building Press. 62.

Wang Y, 2006. Electrochemical-chemical catalytic reduction of nitrate in water. Beijing: Research Center for EcoEnvironmental Sciences, Chinese Academy of Sciences.

Wang Y, Qu J H, Wu R C, Liu H J, 2006. Hydrotalcite-supported $\mathrm{Pd}-\mathrm{Cu}$ catalyst for nitrate adsorption and reduction from water. Chinese Science Bulletin, 51(12): 1431-1438.

Wang Y, Qu J H, Liu H J, 2007a. Effect of liquid property on adsorption and catalytic reduction of nitrate over hydrotalcite-supported Pd-Cu catalyst. Journal of Molecular Catalysis A: Chemical, 272: 31-37.

Wang Y, Qu J H, Liu H J, Hu C Z, 2007b. Adsorption and reduction of nitrate in water on hydrotalcite-supported Pd$\mathrm{Cu}$ catalyst. Catalysis Today, 126(3-4): 476-482.

Weber W J, Morris J C, 1963. Kinetics of adsorption on carbon from solution. J Sanit Eng Div Am Soc Civ Eng, 89: 31-60.

Wu R C, Qu J H, 2004. Removal of Acid Red B from water by surface modified $\mathrm{Fe}_{3} \mathrm{O}_{4}$. Acta Scieniae Circumstantiae, 24(3): 435-439.

Wu R C, Qu J H, He H, 2004. Removal of azo-dye Acid Red $\mathrm{B}(\mathrm{ARB})$ by adsorption and combustion using magnetic $\mathrm{CuFe}_{2} \mathrm{O}_{4}$ powder. Appl Catal B, 48: 49-56.

Wu R C, Qu J H, Chen Y S, 2005. Magnetic powder MnO$\mathrm{Fe}_{2} \mathrm{O}_{3}$-A novel material for the removal of azo-dye from water. Water Res, 39: 630-638.

Xu Y, Langford C H, 1997. Photoactivity of titanium dioxide supported on MCM41, zeolite X, and zeolite Y. J Phys Chem B, 101: 3115-3121.

Xu Y, Zheng W, Liu W, 1999. Enhanced photocatalytic activity of supported $\mathrm{TiO}_{2}$ : dispersing effect of $\mathrm{SiO}_{2}$. J Photochem 
Photobiol A: Chem, 122: 57-60.

Xu T L, Kamat P V, O'Shea K E, 2005a. Mechanistic evaluation of arsenite oxidation in $\mathrm{TiO}_{2}$ assisted photocatalysis. J Phys Chem A, 109(40): 9070-9075.

Xu Y P, Wang Z J, Ke R H, Khan S U, 2005b. Accumulation of organochlorine pesticides from water using triolein embedded cellulose acetate membranes. Environ Sci Technol, 39: $1152-1157$.

Yoneyama H, Torimoto T, 2000. Titanium dioxide/adsorbent hybrid photocatalysts for photodestruction of organic substances of dilute concentrations. Catal Today, 58: 133-140.

Yoshioka T, Kameda T, Miyahara M, Uchida M, Mizoguchi T, Okuwaki A, 2007. Removal of tetrafluoroborate ion from aqueous solution using magnesium-aluminum oxide produced by the thermal decomposition of a hydrotalcitelike compound. Chemosphere, 69(5): 832-835.

Zhang F S, Itoh H, 2006. Photocatalytic oxidation and removal of arsenite from water using slag-iron oxide- $\mathrm{TiO}_{2}$ adsorbent. Chemosphere, 65: 125-131.

Zhang G S, Qu J H, Liu H J, Cooper A T, Wu R C, 2007a. $\mathrm{CuFe}_{2} \mathrm{O}_{4} /$ activated carbon composite: A novel magnetic adsorbent for the removal of acid orange II and catalytic regeneration. Chemosphere, 68: 1058-1066.

Zhang G S, Qu J H, Liu H J, Liu R P, Wu R C, 2007b. Preparation and evaluation of a novel Fe-Mn binary oxide adsorbent for effective arsenite removal. Water Res, 41: 1921-1928.

Zhang G S, Qu J H, Liu H J, Liu R P, Li G T, 2007c. Removal mechanism of $\mathrm{As}(\mathrm{III})$ by a novel Fe-Mn binary oxide adsorbent: oxidation and sorption. Environ Sci Technol, 41: 4613-4619.

Zhang Z L, Hong H S, Zhou J L, Huang J, Yu G, 2003. Fate and assessment of persistent organic pollutants in water and sediment from Minjiang River Estuary, Southeast China. Chemosphere, 52: 1423-1430. 